\title{
A Real-Time RT-PCR Assay for Genotyping of Rotavirus
}

\author{
Seyed Dawood Mousavi-Nasab ${ }^{1,2}$, Farzaneh Sabahi ${ }^{2}$, Hooman Kaghazian ${ }^{1}$, Mahdi Paryan $^{1}$ \\ Siamak Mirab Samiee ${ }^{3}$, Mostafa Ghaderi ${ }^{4}$, Fatemeh Zali ${ }^{5}$ and Manoochehr Makvandi ${ }^{6^{*}}$ \\ ${ }^{1}$ Department of Research and Development, Production and Research Complex, Pasteur Institute of Iran, Tehran, \\ Iran; ${ }^{2}$ Department of Virology, Faculty of Medical Sciences, Tarbiat Modares University, Tehran, Iran; ${ }^{3}$ Reference \\ Health Laboratories Research Microbiology, Karaj Branch, Islamic Azad University, Karaj, Iran; ${ }^{4}$ Department \\ of Microbiology, Karaj Branch, Islamic Azad University, Karaj, Iran; ${ }^{5}$ Department of Clinical Biochemistry, \\ Faculty of Medicine, Tehran University of Medical Sciences, Tehran, Iran; ${ }^{6}$ Infectious and Tropical Diseases \\ Research Center, Health research Institute, Ahvaz Jundishapur University of Medical Sciences, Ahvaz, Iran
}

Received 14 July 2019; accepted 26 December 2019; published online 13 June 2020

\begin{abstract}
Background: HRV is the causative agent of severe gastroenteritis in children and responsible for two million hospitalizations and more than a half-million deaths annually. Sequence characteristics of the gene segments encoding the VP7 and VP4 proteins are used for the genotype classification of rotavirus. A wide variety of molecular methods are available, mainly based on reverse transcription PCR for rapid, specific and sensitive genotyping of rotaviruses. This study describes an alternative real-time PCR assay for genotyping of rotavirus. Methods: The samples of stools studied in this research have been collected from patients referred to Children's Medical Centers, Tehran, Iran. Rotavirus detection and genotyping were performed using the RT-PCR and seminested RT-PCR, respectively. Samples were then genotyped with a new real-time PCR. Results: The real-time PCR was able to genotype all positive samples with a mean $C_{t}$ of 28.2. Besides, a concordance rate of $100 \%$ was detected between real-time PCR and semi-nested RT-PCR. Conclusion: In this study, the genotyping of rotavirus with real-time PCR showed that this method can provide several favorable features, including high sensitivity and specificity, and a wide dynamic range for rotavirus genotyping. DOI: 10.29252/ibj.24.6.394
\end{abstract}

Keywords: Gastroenteritis, Genotype, Real-time polymerase chain reaction, Rotavirus

Corresponding Author: Manoochehr Makvandi

Infectious and Tropical Diseases Research Center, Health research Institute, Ahvaz Jundishapur University of Medical Sciences, Ahvaz, Iran; Tel.: (+98-613) 3354389; Fax: (+98-613) 3361544; E-mail: manoochehrmakvandi29@yahoo.com

\section{INTRODUCTION}

$\mathrm{H}$ uman rotavirus is the most common cause of severe gastroenteritis in infants and young children under the age of five years worldwide, accounting for two million hospitalizations and more than a half-million death every year ${ }^{[1,2]}$. Rotavirus is known to be transmitted person to person by the fecal-oral route. In developing countries, its transmission occurs through contaminated water. Base on reports, rotavirus can spread from child to child via the contamination of hands ${ }^{[3]}$. Rotaviruses are naked double-strand RNA viruses with a segmented genome and are classified as a separate genus (rotavirus) within the family Reoviridae ${ }^{[4]}$. Rotavirus genome is composed of 11 double-strand RNA segments, which are surrounded by the inner capsid proteins, including $\mathrm{VP} 1, \mathrm{VP} 2$, and VP3 ${ }^{[5]}$. VP6 proteins form the middle layer of the virus capsid, and VP4 and VP7 proteins constitute the outer layer ${ }^{[6]}$. The Rotaviruses are currently categorized into eight groups, A through $\mathrm{H}$, according to the group- and subgroup-specific antigens located at the VP6 region ${ }^{[7]}$. Four serogroups of rotavirus, including $\mathrm{A}, \mathrm{B}, \mathrm{C}$, and $\mathrm{H}$, are recognized to be human pathogens. Rotavirus group A is responsible for more than $90 \%$ of all cases ${ }^{[4]}$. Sequence 
characteristics of the segments encoding the VP7 [G, glycoprotein] and VP4 [P, protease-sensitive] are used for serotype and genotype classification. To date, group A rotaviruses have been grouped into at least 27 $\mathrm{G}$ and $37 \mathrm{P}$ genotypes based on the differences in their VP7 and VP4 gene sequences, respectively. Among them, newly $12 \mathrm{G}$ and $15 \mathrm{P}$ genotypes are thought to infect humans ${ }^{[8,9]}$. G1, G2, G4, G9, and G non-type were shown to be the most prevalent $G$ type, while $P$ [8], P [4], and P non-type were found to be the most frequent $P$ type in Iran, respectively ${ }^{[10-12]}$.

Rotavirus classification methods have evolved primarily from antibody-based assays to genetic characterization $^{[13]}$. Sequencing and phylogenetic analyses are currently considered to be the gold standard methods for HRV genotyping ${ }^{[7,14,15]}$.

Nowadays, a wide variety of molecular methods, including Southern blot, Northern blot, reverse line blot hybridization, PCR-ELISA, and RFLP, have been developed for rapid, specific and sensitive genotyping of rotaviruses ${ }^{[16,17]}$. Multiplex semi-nested RT-PCR has been the primary rotavirus genotyping method discriminated by gel electrophoresis based on the amplicon length. Nearly all studies carried out in Iran have used multiplex semi-nested RT-PCR for genotyping HRV. Using high-throughput real-time PCR-based genotyping for rotaviruses has substantially reduced the risk of cross-contamination, resulting in faster turn-around time and higher sensitivity as compared with the conventional multiplex semi-nested RT-PCR ${ }^{[18,19]}$.

The purpose of this study was to investigate the potential value of a real-time PCR method for simple and fast genotyping of HRVs using Iranian strains. In the present study, we attempted to perform the analysis of a TaqMan real-time PCR assay that, to the best of our knowledge, has not yet been used for typing of HRV infections in Iran.

\section{MATERIALS AND METHODS}

\section{Sample collection and processing}

A total of 120 stool samples were obtained from children aged five years and younger with a primary diagnosis of acute non-bloody gastroenteritis who refereed to Children's Medical Center in Tehran, Iran, from May 2013 to May 2014. Criteria for collecting these samples were the absence of leukocytes, red blood cells and pus in the stool. The stools stored at $70{ }^{\circ} \mathrm{C}$ after primary analysis ${ }^{[4]}$.

A $10 \%(\mathrm{w} / \mathrm{v})$ suspension of each stool sample was prepared for RNA extraction. Briefly, one gram (peasized) or $100 \mu \mathrm{l}$ of each stool sample was dissolved in $1000 \mu \mathrm{l}$ of PBS and then centrifuged at $1500 \times \mathrm{g}$ for 20 minutes. Rotavirus RNA was extracted from $100 \mu$ l of the filtered supernatant by a standard phenol-chlorform extraction method ${ }^{[20]}$.

\section{Reverse transcription}

The cDNA was synthesized with the RevertAid RT Reverse Transcription Kit (Thermo Fisher Scientific, USA) according to the manufacturer's instructions. Briefly, reverse transcription was carried out in a final volume of $20 \mu \mathrm{l}$ containing $4 \mu \mathrm{l}$ of $5 \times$ reverse transcription buffer, $1 \mu \mathrm{l}$ of $10 \mathrm{mM}$ dNTPs, $1 \mu \mathrm{l}$ of 0.2 $\mathrm{U} / \mu 1$ random hexamer, $1 \mu \mathrm{l}$ of $40 \mathrm{U} / \mu 1$ RNase inhibitor, $1 \mu \mathrm{l}$ of $200 \mathrm{U} / \mu \mathrm{l}$ reverse transcriptase enzyme, $8 \mu \mathrm{l}$ of diethyl pyrocarbonate (RNase-free water), and $4 \mu$ of the extracted RNA. The tubes were incubated at $42{ }^{\circ} \mathrm{C}$ for 1 hour.

\section{RT-PCR for rotavirus detection}

PCR amplification was carried out in a final volume of $25 \mu \mathrm{l}$ containing $2.5 \mu \mathrm{L}$ of the $10 \times$ PCR buffer (CinnaGen, Iran), $1 \mu \mathrm{L}$ of each $10 \mathrm{pmol} / \mu \mathrm{L}$ primer, 1 $\mu \mathrm{L}$ of $10 \mathrm{mM}$ dNTPs (Fermentas UAB, Lituania), $1 \mu \mathrm{L}$ of $500 \mu / \mu 1$ of Taq DNA polymerase (CinnaGen), 1.5 $\mu \mathrm{L}$ of $50 \mathrm{mM}$ of $\mathrm{MgCl}_{2}$ (CinnaGen), $12 \mu \mathrm{L}$ of $\mathrm{H}_{2} \mathrm{O}$, and $4 \mu 1$ of the cDNA template. Two primers (forward: $5^{\prime}-$ GAC GGV GCR ACT ACA TGG T-3' and reverse: 5'GTC CAA TTC ATN CCT GGT G -3') were used to amplify the VP6 fragment ${ }^{[21]}$. The PCR conditions were set under the following conditions: an initial denaturation at $95{ }^{\circ} \mathrm{C}$ for $5 \mathrm{~min}, 40$ cycles, including denaturation at $94{ }^{\circ} \mathrm{C}$ for $1 \mathrm{~min}$, annealing at $55{ }^{\circ} \mathrm{C}$ for $1 \mathrm{~min}$, elongation at $72{ }^{\circ} \mathrm{C}$ for $1 \mathrm{~min}$, and a final extension step at $72{ }^{\circ} \mathrm{C}$ for $10 \mathrm{~min}$. Amplifications were performed using the Verity ${ }^{\mathrm{TM}}$ 96-well Thermal Cycler (Applied Biosystems, Foster City, CA, USA).

\section{Multiplex semi-nested RT-PCR}

$\mathrm{G}$ and $\mathrm{P}$ typing of HRV-positive samples were obtained by multiplex semi-nested RT-PCR assays using both consensus and type-specific primers, as described previously ${ }^{[20]}$. The PCR products were analyzed on a $2 \%$ agarose gel and visualized using GelRed dye (GelRed ${ }^{\mathrm{TM}}$ Nucleic Acid Gel Stain).

\section{Real-time PCR for rotavirus genotyping}

Recently, Kottaridi et al. ${ }^{[21]}$ developed two panels of real-time RT-PCR assays for the detection of G1-G4 and G9, P [4], and P [8]. In our study, based on multiplex semi-nested RT-PCR result, the genotypespecific primers and probes were adapted or modified $^{[16,21]}$. Both probes and primers were evaluated separately for each genotype based on the most conserved region, using the Allele $\mathrm{ID}^{\circledR}$ (PREMIER Biosoft International) and ClustalW tools. In some cases, degenerate nucleotides were designed to ensure 
the amplification of all HRV genotypes. The oligonucleotides primers and probes were synthesized by Macrogen (Macrogen, South Korea). The six primer pairs, along with six probes labeled with different fluorophores, were used to amplify and detect genotypes G1, G2, G9, P4, P8, and the internal control $(\text { RNase } P)^{[21,22]}$. The details of primers, probes and fluorophore/quenchers are shown in Table 1. To facilitate the use of real-time PCR and to enhance the sensitivity of the assay, three real-time PCR panels were formulated in this study, in which the panel I was designed for the detection of G1 and G2 genotypes, the panel II for the detection of G9 type as well Rnase P as internal control assay, and panel III for the identification of $\mathrm{P}$ [4] and $\mathrm{P}$ [8] genotypes.

Real-time PCR genotyping was carried out in a LightCyclerTM96 system (Roche, Basel, Switzerland) Kottaridi et $a l^{[21]}$ reported various annealing temperatures $\left[55-65^{\circ} \mathrm{C}\right.$ ] with the final concentrations range of 200 to $600 \mathrm{nmol}$ for primers and probes. The real-time PCR reactions were performed in a $25-\mu 1$ final volume, containing $2 \mu \mathrm{l}$ of the cDNA template, $400 \mathrm{nM}$ of each primer, and $200 \mathrm{nM}$ of each probe. The $\mathrm{Ct}$ value was then determined. The amplification was performed under the following thermal conditions: initial denaturation at $95^{\circ} \mathrm{C}$ for $5 \mathrm{~min}, 40$ cycles of denaturation at $95^{\circ} \mathrm{C}$ for $15 \mathrm{~s}$, annealing at $60^{\circ} \mathrm{C}$ for 30 $\mathrm{s}$, elongation at $72{ }^{\circ} \mathrm{C}$ for $30 \mathrm{~s}$, and a final extension step at $72{ }^{\circ} \mathrm{C}$ for $5 \mathrm{~min}$. Based on the $\mathrm{Ct}$ value, the optimal conditions were determined, first for a single reaction and then for a set of multiple panels targeting G1/G2, G9/RNase P, and P4/P8 types.

\section{Evaluation of real-time PCR performance}

The PCR products from each genotype were purified using the QIAquick PCR Clean-up Kit (QIAGEN, Hilden, Germany) and then cloned into the pTZ57R/T vector using the InsTAclone PCR cloning kit (Thermo Fisher Scientific). The plasmid was extracted using the DNA-spin Plasmid DNA Purification Kit (iNtRON Biotechnology, South Korea). Plasmid concentration was determined by measuring UV absorbance at 260 $\mathrm{nm}$. The plasmid was then diluted in a Tris-EDTA buffer. Relative sensitivity and lower limit of detection of the assay determine the base of tenfold serial dilutions of each plasmid.

To assess the specificity and possible false-positive detection by the genotype-specific primer-probe sets, the positive samples for human adenovirus, norovirus, sapovirus, Escherichia coli, campylobacter, Cryptosporidium, and Giardia lamblia were investigated in this study. Additionally, partial sequencing was performed for 12 out of the 28 specimens to verify the accuracy of HRV genotyping by real-time PCR. Analysis of sequencing was blasted to determine the nucleotide identity (NCBI database) and further analysis was performed using MEGA version $6^{[23]}$.

\section{Statistical analysis}

Comparison test was used to assess the consistency of real-time PCR and multiplex semi-nested RT-PCR results. A $p$ value of less than 0.05 was considered to be statistically significant.

Table 1. Primers and probes used for rotavirus genotyping by real-time PCR

\begin{tabular}{|c|c|c|c|}
\hline Genotype & Primer sequences & Probe sequences & $\begin{array}{c}\text { Fluorophore/ } \\
\text { quencher }\end{array}$ \\
\hline $\begin{array}{l}\text { G1F } \\
\text { G1R }\end{array}$ & $\begin{array}{l}\text { AGCTGATTTGATATTGAATGAATGG } \\
\text { CACAGTACAYGATGATCCCATTG }\end{array}$ & TCCACTTATTYGATTCTCCCGATTGYT & FAM/BHQ1 \\
\hline $\begin{array}{l}\text { G2F } \\
\text { G2R }\end{array}$ & $\begin{array}{l}\text { ACATTTGAGATTGTTGCVTCGTCTG } \\
\text { TGGAACTGTYGTTGGATCAGCAG }\end{array}$ & AGTGCRTTCGGTCCACCAACTTGAA & HEX/BHQ1 \\
\hline $\begin{array}{l}\text { G9F } \\
\text { G9R }\end{array}$ & $\begin{array}{l}\text { ACTTGATGTDACTACAAATACCTG } \\
\text { TGTGGTGYAGTAGTTGGATCYG }\end{array}$ & ATCTAACACATCTGAGCCACCGACTTG & HEX/BHQ1 \\
\hline $\begin{array}{l}\text { P4F } \\
\text { P4R }\end{array}$ & $\begin{array}{l}\text { TGAYGAAATAGARCAGATTGGATC } \\
\text { CCATCTAAAAYTGGTTCCACTG }\end{array}$ & AATCTCTCCGTGTCCCCAATYRACTG & FAM/BHQ1 \\
\hline $\begin{array}{l}\text { P8F } \\
\text { P8R }\end{array}$ & $\begin{array}{l}\text { TAGACGTACACTAACTTCTGATAC } \\
\text { TTGARCTATCRGTAGTAGCC }\end{array}$ & CACCATGAAATGTCCATATTCTTCCACC & HEX/BHQ1 \\
\hline $\begin{array}{l}\text { RNase PF } \\
\text { RNase PR }\end{array}$ & $\begin{array}{l}\text { AGA TTT GGA CCT GCG AGC G } \\
\text { GAG CGG CTG TCT CCA CAA GT }\end{array}$ & TTCTGA CCTGAA GGCTCT GCG CG & FAM/BHQ1 \\
\hline
\end{tabular}

$F$, forward; $R$, reverse 


\section{Ethical statement}

The above-mentioned sampling protocols were approved by Tarbiat Modares University, Tehran, Iran (ethical code: 52/5140). A verbal consent and interview were taken from either parents of the enrolled child prior collection of stool samples.

\section{RESULTS}

In the present study, $28(23.3 \%)$ patients were found to be positive for HRV infection by RT-PCR method based on VP6 gene of rotavirus. The $G$ and $P$ genotypes were detected in 28/120 patients by multiplex semi-nested RT-PCR. Overall, G1 (75\%) was found to be the most dominant genotype, followed by G2 (14.3\%), G9 (7.14\%), and mixed $\mathrm{G} 1 / \mathrm{G} 2$ (3.58\%). Moreover, in terms of $\mathrm{p}$ genotypes, P8 (75\%) and P4 (25\%) were dominant. Surprisingly, the G4 and G8 genotypes were not detected.

\section{Performance criteria for real-time PCR genotyping Accuracy and specificity}

Accuracy of RNA extraction and amplification were confirmed by the production of a signal from the RNase P internal control. There were no false-positive or false-negative results among the patients with the expected VP7 and VP4 genotypes. Regarding the isolated HRVs, no cross-reactivity was observed for adenovirus, strovirus, norovirus GI, norovirus GII, sapovirus, Escherichia coli, campylobacter, cryptosporidium, and Giardia lamblia. The results obtained by real-time PCR genotyping and partial sequencing of the amplified product showed 100\% concordance to the both assays.

\section{Correlation between real-time PCR and multiplex semi-nested RT-PCR}

Both real-time PCR and multiplex semi-nested RTPCR were able to detect all the $28(100 \%)$, and the mean $\mathrm{C}_{\mathrm{t}}$ value was 28.2.

\section{Limit of detection}

To evaluate real-time PCR efficiency, standard curves were constructed using serial dilutions (from $10^{-1}$ to $10^{-10}$ ) each plasmid. The lowest average of 10 copies per reaction could detect $100 \%$ of all known HVR genotypes, which have been identified in this study. The panel targeting the mixed G1/G2 genotypes yielded an $r^{2} \geq 0.94$, while the panel targeting G9/RNase $P$ and P4/P8 provided an $r^{2} \geq 0.99$ for the standard curve (Table 2 and Fig. 1)

\section{DISCUSSION}

The severe gastroenteritis due to HRV occurs annually throughout the world, especially in developing countries, with high morbidity and mortality rates. The prevalence of different rotavirus genotypes varies in different geographical areas ${ }^{[24,25]}$. Interestingly, by using multiplex nested RT-PCR, the G1, G2, G9, mixed G1/G2, P4, and P8 genotypes were detected for VP7 and VP4; however, we did not detect some of the genotypes, such as G4 and G8 $8^{[10,11]}$. The absence of these genotypes in our study is probably due to the geographical sampling bias. Although multiplex semi-nested RT-PCR assay has been recommended by WHO for HRV genotyping, this method is slow and prone to contamination. Moreover, the turn-around time for multiplex semi-nested RTPCR assay is higher than real-time PCR assey ${ }^{[20,21]}$. The application of real-time PCR is generally regarded as a diagnostic tool since it provides quick, quantitative and reliable measurements. Furthermore, because realtime PCR-based genotyping methods were proved to be significantly cost-effective, this technique can serve as an alternative tool to the multiplex semi-nested RTPCR method. Kottaridi et al. ${ }^{[21]}$ was applied the realtime PCR as a diagnostic tool for rotavirus genotyping, but in developing countries, because of genetic diversity and co-infection with other gastrointestinal pathogens, it is required to re-evaluate molecular techniques for the determination of rotavirus genotypes $^{[26,27]}$. Therefore, these issues highlight the need for the analysis of a method that would allow the cost-effective, rapid and highly sensitive detection of HRV genotypes with a wider dynamic range. To the best of our knowledge, this is the first time that the real-time PCR assay has been utilized for the detection of HRV genotypes in Iran. For this purpose, the realtime PCR used to determine the G-P assay of rotavirus with TaqMan probes.

The results of our TaqMan RT-PCR assay showed high accuracy and excellent correlation with conventional multiplex semi-nested RT-PCR and sequencing. The presented method also demonstrated high specificity and no cross-reaction with the above-

Table 2. Real-time PCR performance for rotavirus genotyping

\begin{tabular}{lcc}
\hline $\begin{array}{l}\text { Genotype } \\
\text { panel }\end{array}$ & $\boldsymbol{r}^{\mathbf{2}}$ & $\begin{array}{c}\text { Average } \\
\text { efficiency (\%) }\end{array}$ \\
\hline G1/G2 & $\geq 0.94$ & 98 \\
G9/RNase P & $\geq 0.99$ & 97 \\
P4/P8 & $\geq 0.99$ & 95 \\
\hline
\end{tabular}




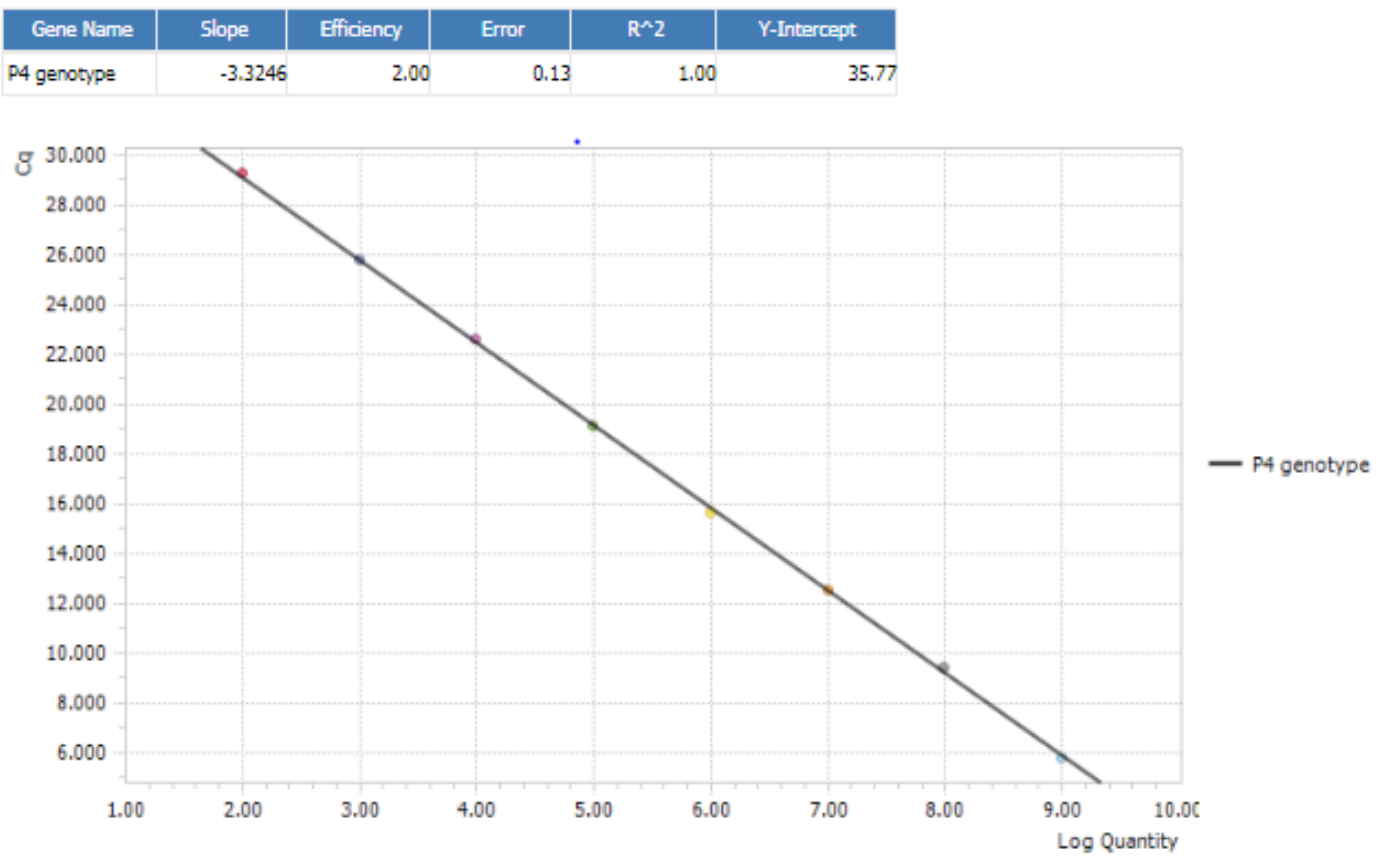

Fig. 1. Limit of detection and real-time PCR performance for rotavirus P4 genotyping on LightCycler 96 system.

mentioned pathogens. This assay with a lower limit of detection 10 copy/reaction was sensitive. Regrettably, we were not able to evaluate other HRV genotypes due to the limitation in the availability of samples in other geographical regions of Iran.

In conclusion, the rapid and cost-effective in-house real-time PCR assay evaluated herein for the HRV genotyping revealed high sensitivity and specificity, significantly shortened reaction time, and a wider dynamic range.

\section{ACKNOWLEDGMENTS}

This project was partially supported under the grant number U-93050 by Deputy Research, Ahvaz Jundishapur University of Medical Sciences, and Ahvaz, Iran.

CONFLICT OF INTEREST. None declared.

\section{REFERENCES}

1. Parashar UD, Gibson CJ, Bresee JS, Glass RI. Emerging infectious diseases 2006; 12(2): 304-306.

2. Tate JE, Burton AH, Boschi-Pinto C, Steele AD, Duque J, Parashar UD. 2008 estimate of worldwide rotavirusassociated mortality in children younger than 5 years before the introduction of universal rotavirus vaccination programmes: a systematic review and metaanalysis. The lancet infectious diseases 2012; 12(2):
136-141.

3. Dennehy PH. Transmission of rotavirus and other enteric pathogens in the home. The pediatric infectious disease journal 2000; 19(10): S103-S105.

4. Nasab SDM, Sabahi F, Makvandi M, Samiee SM, Nadji SA, Ravanshad M. Epidemiology of rotavirus-norovirus Co-Infection and determination of norovirus genogrouping among children with acute gastroenteritis in Tehran, Iran. Iranian biomedical journal 2016; 20(5): 280-286.

5. Lu X, McDonald SM, Tortorici MA, Tao YJ, VasquezDel Carpio R, Nibert ML, Mechanism for coordinated RNA packaging and genome replication by rotavirus polymerase VP1. Structure 2008; 16(11): 1678-1688.

6. Malik J, Bhan MK, Ray P. Natural immunity to rotavirus infection in children. Indian journal of biochemistry and biophysics 2008; 45(4): 219-228.

7. Matthijnssens J, Ciarlet M, McDonald SM, Attoui H, Bányai K, Brister JR, Buesa J, Esonna MD, Estes Mk, Gentsch JR, Itueeiza-Gómara M, Johne R, Kirkwood CD, Martella PP, Nakagomi O, Parreno V, Rahman M, Ruqqeri FM, Saif LJ, Santos N, Stever A, Taniquuchi $\mathrm{K}$, Patton JT, Desseelberger U, Van Ranst $\mathrm{M}$. Uniformity of rotavirus strain nomenclature proposed by the rotavirus classification working group [RCWG]. Archives of virology 2011; 156(8): 1397-1413.

8. Tort LF, Victoria M, Lizasoain A, García M, Berois M, Cristina J, Leite JP, Gómez MM, Miagostovich MP, Colina R. Detection of common, emerging and uncommon VP4 and VP7 human group A rotavirus genotypes from urban sewage samples in uruguay. Food and environmental virology 2015; 7(4): 342-353.

9. Bányai K, László B, Duque J, Steele AD, Nelson EAS, Gentsch JR, Parashar UD. Systematic review of regional 
and temporal trends in global rotavirus strain diversity in the pre rotavirus vaccine era: insights for understanding the impact of rotavirus vaccination programs. Vaccine 2012; 30(1): 122-130.

10. Mousavi Jarrahi Y, Zahraei SM, Sadigh N, Esmaeelpoor Langeroudy K, Khodadost M, Ranjbaran M, The cost effectiveness of rotavirus vaccination in Iran. Human vaccines and immunotherapeutics 2016; 12(3): 794-800.

11. Rahbarimanesh AA, Sayari AA. Modarres SH, Edalat $\mathrm{R}$, Sohrabi A. Human rotavirus genotypes detection among hospitalized children, a study in Tehran, Iran. Archives of Iranian medicine 2011 ; 4(1): 39-45.

12. Khoshdel A, Parvin N, Doosti A, Eshraghi A. Prevalence and molecular characterization of rotaviruses as causes of nosocomial diarrhea in children. Turkish journal of pediatrics 2014; 56(5): 469-474.

13. Desselberger U. Differences of rotavirus vaccine effectiveness by country: likely causes and contributing factors. Pathogens 2017; 6(4): 65.

14. Matthijnssens J, Bilcke J, Ciarlet M, Martella V, Bányai K, Rahman MzELLER m,Beutels P,Van Damme P,Van Rant M. Rotavirus disease and vaccination: impact on genotype diversity. Future microbiology 2009; 4(10): 1303-1316.

15. Vinjé J. Advances in laboratory methods for detection and typing of norovirus. Journal of clinical microbiology 2015; 53(2): 373-381.

16. Liu J, Lurain K, Sobuz SU, Begum S, Kumburu H, Gratz J, Toney D, Gautam R, Bowen W, Petri WA, Haque R, Houpt ER. Molecular genotyping and quantitation assay for rotavirus surveillance. Journal of virological methods 2015; 213: 157-163.

17. Gunson RN, Miller J, Leonard A, Carman WF. Importance of PCR in the diagnosis and understanding of rotavirus illness in the community. Communicable disease and public health 2003; 6(1): 63-65.

18. Pang XL, Lee B, Boroumand N, Leblanc B, Preiksaitis $\mathrm{JK}, \mathrm{Yu}$ Ip CC. Increased detection of rotavirus using real time reverse transcription-polymerase chain reaction [RT-PCR] assay in stool specimens from children with diarrhea. Journal of medical virology
2004; 72(3): 496-501.

19. Khamrin P, Okame M, Thongprachum A, Nantachit N, Nishimura S, Okitsu S, Maneekarm N, Shijima H. A single-tube multiplex PCR for rapid detection in feces of 10 viruses causing diarrhea. Journal of virological methods 2011; 173(2): 390-393.

20. Organization WH. Manual of Rotavirus detection and characterization methods. 2009; Reterieved from: https://apps.who.int/iris/handle/10665/70122.

21. Kottaridi C, Spathis AT, Ntova CK, Papaevangelou V, Karakitsos P. Evaluation of a multiplex real time reverse transcription PCR assay for the detection and quantitation of the most common human rotavirus genotypes. Journal of virological methods 2012; 180(12): 49-53.

22. Boddicker JD, Rota PA, Kreman T, Wangeman A, Lowe L, Hummel KB, Thompson R, Bellini W, Pentella $\mathrm{M}$, Desjardin L. Real-time reverse transcription-PCR assay for detection of mumps virus RNA in clinical specimens. Journal of clinicalmicrobiology 2007; 45(9): 2902-2908.

23. Tamura K, Stecher G, Peterson D, Filipski A, Kumar S. MEGA6: molecular evolutionary genetics analysis version 6.0. Molecular biology and evolution 2013; 30(12): 2725-2729.

24. Kotirum S, Vutipongsatorn N, Kongpakwattana K, Hutubessy R, Chaiyakunapruk N. Global economic evaluations of rotavirus vaccines: A systematic review. Vaccine 2017; 35(26): 3364-3386.

25. Kollaritsch H, Kundi M, Giaquinto C, Paulke-Korinek M. Rotavirus vaccines: a story of success. Clinical microbiology and infection 2015; 21(8): 735-743.

26. Kirkwood CD, Steele AD. Rotavirus vaccine will have an impact in Asia. PLoS medicine 2017; 14(5): e1002298.

27. Tissera MS, Cowley D, Bogdanovic-Sakran N, Hutton ML, Lyras D, Kirkwood CD, Buttery JP. Options for improving effectiveness of rotavirus vaccines in developing countries. Human vaccines and immunotherapeutics 2017; 13(4): 921-927. 